\title{
PERANAN EKONOMI SYARÎ'AH DI TENGAH KRISIS GLOBAL
}

\author{
Sakinah \\ (D osen Jurusan Syari'ah STAIN Pamekasan, JI. Raya Panglegur Km. 04 \\ Pamekasan)
}

\begin{abstract}
Abstraks:
At the end of 2008, the super power United States suffered from economic crisis. It shocked the world since US economic policy legalizes capitalism. Not only US experienced the crisis but also other countries did, including Indonesia. The crisis repeatedly occurs many times however it is unstoppable Only those that apply Islamic economic system endures the crisis. They are A rabian countries. The questions had been purposed is that how come the capitalism easily injured crisis? The hypothetical answer is that because economic capitalism allows the practice of maghrib, the acronym of maysir, gharar, and riba'. These have been insulted in Syariah economical system. Ironically, these three concepts of capitalism have been applied and adopted by conventional banking such as stock exchange, insurances and money market. These are suspiciously caused the downfall of conventional financing system. This brief article is about to describe the prohibition of riba (bribery) practice.
\end{abstract}

\section{Pendahuluan}

Kata kunci:

ekonomi syarî’ah, krisis global, dan ribâ

Memasuki awal tahun 2009 ini, dunia dikejutkan oleh berbagai macam krisis runtuhnya perekonomian dunia yang bermula dari Amerika Serikat yang nota beni menganut paham kapitalisme. ${ }^{1}$

\footnotetext{
${ }^{1}$ A da 4 macam sistem perekonomian dunia, yaitu kapitalisme, sosialisme, fasisme dan komunisme. Kapitalisme merupkan suatu falsafah ekonomi, bukan bentuk suatu pemerintahan. Dalam sistemini seseorang bebas untuk memiliki kekayaan, memiliki perusahaan, berasing secara bebas dalam pasar dan menentukan miliknya dengan sebebas-bebasnya (kebebasan ini disebut laisses faire; sosialisme merupakan suatu
} 
Bencana keuangan ini tengah melanda negara tersebut. Beberapa bank raksasa kelas dunia yang telah mengurita ke berbagai penjuru dunia kini rontok satu persatu. Dimulai dari bangkrutnya bank raksasa Lehman Brothers dan perusahaan finansial raksasa Bear Strearn. Berbagai saat sebelumnya,, pemerintah Amerika terpaksa mengambil alih perusahaan Montgage terbesar di Amerika, Gredie Mac dan Fanni Mae. Sementara Merrill Lynch mengalami kondisi tak jauh beda sehingga harus diakuisisi oleh Bank of A merica. Terakhir perusahaan asuransi terbesar AIG (America International Group) menunjukkan gejala kristis yang sama.

Untuk mengatasi badai krisis yang hebat itu dan menyelamatkan bank-bank raksasa yang terpuruk, pemerintah AS terpaksa menyuntikkan bailout sebesar 700 Milyar dolar keuangan di negeri paman Sam itu merupakan kebijakan yang bertentangan dengan paham pasar bebas (kapitalisme) yang di anut oleh AS. Nyatanya dana suntikan yang mirip dengan BLBI itu tidak dapat membendung terpaan badai krisis yang begitu dahsyat, kebijakan bailout ini, tidak saja dilakukan oleh pemerintah AS, tetapi juga dilakukan oleh bank sentral Eropa dan Asia turun tangan menyuntikkan dana untuk mendorong likuiditas perekonomian, sehingga diharapkan dapat mencegah efek domino dari ambruknya bank-bank investasi kelas dunia tersebut.

Beberapa saat setelah informasi kebangkrutan Lehman Brother

sistem perekonomian sekaligus untuk memilih sumber daya yang diinginkan tetapi pemerintah ikut campur tangan dengan berusaha menyesuaikan kebutuhan individu-individu kepada kebutuhan masyarakat). Fasisme merupakan suatu sistem perekonomian dan bentuk pemerintahan (biasanya diktator) di mana pemerintah memiliki semua industri. Dal am hal ini orang bebas memilih sumber-sumber yang di inginkan atas persetujuan pemerintah. Sedangkan komunisme juga merupakan sistem perekonomian sekaligus bentuk pemerintahan. Dalam komunisme ini tidak terdapat kekayaan pribâdi atau mungkin hanya sedikit dan tidak terdapat motif keuntungan pekerjaan ditentukan oleh negara setiap orang bekerja untuk kepentingan masyarakat secara keseluruhan. Pemerintah menentukan siap yang boleh memproduksi barang atau jasa dan macam-macam barang atau jasa apa saja yang harus di buat, juga banyaknya, untuk siapa dan menggunakan alat-alat apa seperti fisisme, kebebasan politik diawasi secara ketat. Lihat Basu Swastha dan Ibnu Sukotjo, Pengantar Bisnis M odern: Pengantar Perusahaan M odern, (Yogyakarta: BPFE, 2001), hlm., 71-72; dan Manullag, Pengantar Bisnis (Yogyakarta: Gajah Mada University Press, 2002), hlm., 27-29. 
pasar keungan dunia mengalami terjun bebas di tingkat terendah. ${ }^{2}$ Peristiwa banyaknya bank yang Collaps dan runtuhnya berbagai bank investasi kaitannya di AS segera memicu gelombang kepanikan di berbagai pusat keuangan di seluruh dunia. Kepanikan-kepanikan dunia (AS, Eropa, dan Asia) mengakibatkan jatuhnya indeks harga terjun bebas ke jurang yang dalam. Pasar modal London mencatat rekor kejatuhan terburuk dalam sehari yang mencapai penurunan $8 \%$, sedangkan Jerman dan Prancis masing-masing ditampar dengan kejatuhan pasar Modal sebesar 7\% dan 9\%. Pasar modal emerging market seperti Rusia, Argentina dan Brasil juga mengalami keterpurukan yang sangat buruk yaitu 15\%, 11\% dan 15\%. ${ }^{3}$

Sejak awal 2008, bursa saham China anjlok 57 \%, India 52\%, Indonesia $41 \%$ (sebelum kegiatannya dihentikan untuk sementara) dan zona Eropa 37\%, sementara pasar surat utang terpuruk, mata uang negara berkembang melemah dan harga komuditas anjlok, komoditas anjlok, apalagi setelah para spekulator mengurangi konsumsi energi dunia. ${ }^{\mathrm{D} \text { D AS }}$ bursa saham Wall Street terus merosot, Dow Jones 5 sebagai episentrum pasar modal dunia jatuh pada level yang terburuk dalam 4 tahun terakhir yaitu berada di bawah angka 10.000. Dalam rangka mengantisipasi krisis keuangan-keuangan tersebut, tujuh bank sentral (termasuk US Federal Reserve, European, Central Bank, Bank Of England dan Bank Of Canada) memangkas suku bunganya 0,5\%. Ini merupakan yang pertamakalinya kebijakan suku bunga bank sentral dilakukan secara bersamaan dalam skala yang besar.

Berdasarkan fakta dan realita yang terjadi saat ini jelas sekali krisis keuangan memasuki tingkat keterpurukan yang amat dalam bahkan dapat dikatakan, krisis finansial Amerika saat ini jauh lebih

2 Dalam hal ini, Jawa Pos memberitakan bahwa Madoff (70 th), seorang pakar keuangan, mantan Bos pasar saham NASDAQ dan mantan orang terkaya di AS, mengaku telah melakukan penipuan Rp. 777,6 triliun dan akan dihukum 150 thn, dengan berkedok sebagai investasi. Lihat Jawa Pos, M adoff Dijebloskan ke Sel WC, 9 Maret 2009.

3 STAN, Global Stock M arket A mbruk: http:/ / www.exalumni.com/ exalumni/ news.php? item.16. (Diakses pada 28 Desember 2008)

4 Ibid.

5 Down Jones, "Dow Jones is a leading provider of global business news and information services", Vibiz news: http:/ / www.dow Jones. Com. (Diakses pada 29 Desember 2008) 
parah dari krisis Asia yang terjadi di tahun 1997-1998. Dampak krisis saat ini demikian terasa mengenaskan terhadap pergerakan keuangan global, pada saat itu (krisis A sia) setidaknya masih ada "seruan aman" atau "save heaven" bagi para investor global yaitu AS, Eropa dan Jepang, tetapi kini semua pasar modal rontok dan para investor panik.

Oleh karena itu, seluruh pengamat ekonomi sepakat bahwa guncangan ekonomi akibat badai keuangan yang melanda Amerika merupakan guncangan yang terparah setelah Great Depresion pada tahun 1930, bahkan IMF menilai guncangan sektor finansial kali ini merupakan yang terparah sejak era 1930_an. Hal itu diperkirakan akan menggerus pertumbuhan ekonomi dunia melambat menjadi 3\% pada tahun 2009 atau 0,9\% point lebih rendah dari proyeksi Word Economic O utlook pada Juli 2009.6

Indonesia juga terkena dampaknya. Pada tanggal 8 Oktober 2008, kemarin, IHSG tertekan tajam turun 10,38 \%, yang membuat pemerintah panik dan terpaksa menghentikan (suspen) kegiatan pasar modal beberapa hari. Demikian pula Nikken di Jepang jatuh lebih dari $9 \%$. Pokoknya, hampir semua pasar keuangan dunia terimbas krisis finansial US tersebut. Karena itu para pengamat menyebut krisis ini sebagai krisis finansial global. Krisis keuangan global yang terjadi belakangan ini, merupakan fenomena yang mengejutkan dunia, tidak saja bagi pemikir ekonomi mikro dan makro, tetapi juga bagi para elite politik dan para pengusaha.

Dari data-data paparan di atas, terlihat dengan nyata bahwa sistem ekonomi kapitalisme yang menganut laize faire dan berbasis ribâ kembali tergugat paham neo-liberalisme tidak bisa dipertahankan. Apa yang dilakukan Fukugama yang mendeklarasikan kemenangan kapitalisme liberal sebagai representasi akhir zaman "The End Of History". Karena sistem kapitalisme telah gagal menciptakan tata ekonomi yang berkeadilan dan stabil. ${ }^{7}$

Oleh karena itu, peristiwa-peristiwa tersebut di atas menarik sekali untuk dikaji dan menimbulkan pertanyaan-pertanyaan

6 IMF, "What the World Bank Is Doing",The Economic Crisis, (29 November 2008): http:/ / www.IMF.org./ External/ pubind , (Diakses pada 4Januari 2009)

7 Suharwadi K. Lubrs, H ukum Ekonomi Islam (Jakarta: Sinar Grafika, 2004). 
Peranan Ekonomi Syarî'ah

mengapa sistem ekonomi kapitalis yang sudah bercokol ratusan tahun malah mengalami krisis/ rontok dan bagaimana peranan ekonomi syarî'ah mencoba menggali ajaran-ajaran Islâm yang fundamental dalam kegiatan ekonomi yaitu larangan melakukan praktik ribâ8 dan probability, yang menjadi pemicu krisis ekonomi.

\section{Sejarah Krisis Perbankan Internasional ${ }^{9}$}

Pada tahun 1907 krisis perbankan internasional dimulai di New York, setelah beberapa dekade sebelumnya yakni mulai tahun 1860-1921 terjadi peningkatan hebat jumlah bank di Amerika sampai dengan 19 kali lipat. Selanjutnya, tahun 1920 terjadi depresi ekonomi di Jepang. Kemudian pada tahun 1922 - 1923 Jerman mengalami krisis dengan hyper inflasi yang tinggi. Karena takut mata uang menurun nilainya, gaji dibayar sampai dua kali dalam sehari. Selanjutnya, pada tahun 1927 krisis keuangan melanda Jepang (37

8 Definisi ribâ menurut bahasa berarti tambahan, sedangkan menurut syara' arti ribâ adalah tambahan yang diperoleh dari seseorang yang meminjam ( barang atau uang ) dengan tempo atau batas waktu. Menurut 'Alî bin Muhammad al-Durjanî, ribâ adalah tambahan yang tidak menjadikan imbalan sebagai sesuatu yang diisyaratkan bagi salah seorang yang meminjam dan memberi pinjaman. Makna ribâ yang lebih baik disampaikan oleh Syaykh Abd al-Rahman Taj, bahwa ribâ adalah setiap tambahan yang berlangsung pada salah satu pihak dal am akad mu'awwadhah tanpa mendapat imbalan; atau tambahan itu diperoleh karena penangguhan. Lihat alThabarî, Tafsir al-Thabari, jilid I (Kairo: Dar al-Kitab al-'A rabiy, 1951), hlm., 388 ; alQurthubî, Tafsîr al-Q urthubi, jilid I (Kairo: Dar al-Kutub, 1967), hlm,. 348 ; Imam alSyawkanî, Fath al-Q âdir jilid I (Beirut: Dar al-Fikr, 1971), hlm., 249; Muhammad 'Alî al-Shabûnî, Tafsir Ayat al-A hkâm jilid I (Lebanon: al-'Alamî, t.th.), hlm., 421 ; dan Muhammad 'Ali al-Sâis, Tafsîr Ayat al-A hkâm (Beirut: Dar al-Fikr, 1983), hlm., 162. Pada awal nya ribâ hanya ada 2 ( dua ) macam, yaitu ribâ nasí'ah dan ribâ fadl. Menurut pengikut Imam Syafi'i ribâ ada 3 ( tiga ) macam, yaitu ribâ fadl yang di dalamnya termasuk ribâ qardh, ribâ nasi'ah dan ribâ yad. Sedangkan makna dari masing-masing definisi adalah sebagai berikut: (1) Ribâ nasi'ah adalah praktik ribâ memberikan hutangan kepada orang lain dengan tempo, jika terlambat mengembalikan akan dinaikkan jumlah / nilainya sebagai tambahan atau sanksi. (2) Ribâ fadhl praktik ribâ dalam bentuk menukarkan barang yang sejenis tetapi saling berbeda nilainya. (3) Ribâ qardh praktek ribâ dengan cara meminjamkan kepada seseorang dengan syarat ada kelebihan/ keuntungan bagi pihak pemberi hutang. Dan (4) Ribâ yadd adalah praktik ribâ yang dilakukan oleh pihak peminjam, yang meminjamkan uang/ barang berpisah dari tempat akad sebelum diadakan serah terima barang (akad timbang terima).

9 Data-data yang disajikan di bawah ini diambil dari A gustianto, Telaah Terhadap A kar Krisis Keuangan Global - M omentum Ekonomi Syariah Sebagai Solusi: Percikan Ekonomi Islam, http:/ / Agustianto.niriah.com. (Diakses pada 13 oktober 2008) 
Bank tutup); akibat krisis yang terjadi pada bank-bank Taiwan

Pada tahun 1929 - 1930 The Great Crash (di pasar modal NY) dan Great Depression (Kegagalan Perbankan); di US, hingga net national product-nya terpangkas lebih dari setengahnya. Selanjutnya, pada tahun 1931 Austria mengalami krisis perbankan, akibatnya kejatuhan perbankan di Jerman, yang kemudian mengakibatkan berfluktuasinya mata uang internasional. Hal ini membuat UK meninggalkan standard emas. Kemudian1944 - 66 Prancis mengalami hyper inflasi akibat dari kebijakan yang mulai meliberalkan perekonomiannya. Berikutnya, pada tahun 1944 - 1946 Hungaria mengalami hyper inflasi dan krisis moneter. Ini merupakan krisis terburuk eropa. N ote issues Hungaria meningkat dari 12000 million (11 digits) hingga 27 digits.

Pada tahun 1945 - 1948 Jerman mengalami hyper inflasi akibat perang dunia kedua.. Selanjutnya tahun 1945 - 55 Krisis Perbankan di Nigeria A kibat pertumbuhan bank yang tidak teregulasi dengan baik pada tahun 1945. Pada saat yang sama, Perancis mengalami hyper inflasi sejak tahun 1944 sampai 1966. Pada tahun (1950-1972) ekonomi dunia terasa lebih stabil sementara, karena pada periode ini tidak terjadi krisis untuk masa tertentu. Hal ini disebabkan karena Bretton Woods Agreements, yang mengeluarkan regulasi di sektor moneter relatif lebih ketat (Fixed Exchange Rate Regime). Disamping itu IMF memainkan perannya dalam mengatasi anomali-anomali keuangan di dunia. Jadi regulasi khususnya di perbankan dan umumnya di sektor keuangan, serta penerapan rezim nilai tukar yang stabil membuat sektor keuangan dunia (untuk sementara) "tenang".

Namun ketika tahun 1971 Kesepakatan Breton Woods runtuh (collapsed). Pada hakikatnya perjanjian ini runtuh akibat sistem dengan mekanisme bunganya tak dapat dibendung untuk tetap mempertahankan rezim nilai tukar yang fixed exchange rate. Selanjutnya pada tahun 1971-1973 terjadi kesepakatan Smithsonian (dimana saat itu nilai 1 Ons emas = 38 USD). Pada fase ini dicoba untuk menenangkan kembali sektor keuangan dengan perjanjian baru. Namun hanya bertahan 2-3 tahun saja.

Pada tahun 1973 A merika meninggalkan standar emas. Akibat hukum "uang buruk (foreign exchange) menggantikan uang bagus (dollar yang di-back-up dengan emas)-(Gresham Law)". Pada tahun 1973 dan sesudahnya mengglobalnya aktifitas spekulasi sebagai 
dinamika baru di pasar moneter konvensional akibat penerapan floating exchange rate sistem. Periode Spekulasi; di pasar modal, uang, obligasi dan derivative. Maka tak aneh jika pada tahun 1973 - 1874 krisis perbankan kedua di Inggris; akibat Bank of England meningkatkan kompetisi pada supply of credit.

Pada tahun 1974 Krisis pada Eurodollar M arket; akibat West German Bankhaus ID Herstatt gagal mengantisipasi international krisis. Selanjutnya tahun 1978-1980 D eep recession di negara-negara industri akibat boikot minyak oleh OPEC, yang kemudian membuat melambung tingginya interest rate negara-negara industri.

Selanjutnya sejarah mencatat bahwa pada tahun 1980 krisis dunia ketiga; banyaknya hutang dari negara dunia ketiga disebabkan oleh oil booming pada tahun 1974, tapi ketika negara maju meningkatkan interest rate untuk menekan inflasi, hutang negara ketiga meningkat melebihi kemampuan bayarnya. Pada tahun 1980 itulah terjadi krisis hutang di Polandia; akibat terpengaruh dampak negatif dari krisis hutang dunia ketiga. Banyak bank di eropa barat yang menarik dananya dari bank di eropa timur.

Pada saat yang hampir bersamaan yakni di tahun 1982 terjadi krisis hutang di Mexico; disebabkan outflow kapital yang massive ke US, kemudian di-treatment dengan hutang dari US, IMF dan BIS. Krisis ini juga menarik Argentina, Brazil dan Venezuela untuk masuk dalam lingkaran krisis. Perkembangan berikutnya, pada tahun 1987 The Great Crash (Stock Exchange), 16 Oktober 1987 di pasar modal US dan UK ${ }^{10}$. Mengakibatkan otoritas moneter dunia meningkatkan money supply. Selanjutnya pada tahun 1994 terjadi krisis keuangan di Mexico; kembali akibat kebijakan finansial yang tidak tepat.

Pada tahun 1997-2002 krisis keuangan melanda Asia Tenggara; krisis yang dimulai di Thailand, Malaysia kemudian Indonesia, akibat kebijakan hutang yang tidak transparan. Krisis keuangan di Korea; memiliki sebab yang sama dengan Asia Tengara.

Kemudian, pada tahun 1998 terjadi krisis keuangan di Rusia; dengan jatuhnya nilai Rubel Rusia (akibat spekulasi) Selanjutnya krisis keuangan melanda Brazil di tahun 1998. pad saat yang hamper bersamaan krisis keuangan melanda Argentina di tahun 1999.

\footnotetext{
10 Tim Penulis MSI UII, M enjawab Keraguan Berekonomi Syariah, (Yogyakarta: MSI UII
} dan Safiria Insania Press, 2008), hlm. 21. 
Terakhir, pada tahun 2007-hingga saat ini, krisis keuangan melanda A merika Serikat.

Dari data dan fakta historis tersebut terlihat bahwa dunia tidak pernah sepi dari krisis yang sangat membayakan kehidupan ekonomi umat manusia di muka bumi ini.

\section{Larangan M elakukan Praktik Ribâ}

Islâm adalah satu-satunya agama besar yang mempertahankan keharaman ribâ11. Larangan Islâm atas ribâ merupakan otoritas al-Qur'ân suci yang tiada bandingannya, di mana pengharaman ribâ berulang kali dinyatakan dengan jelas 12 meskipun dalam hal ini umat Islâm sendiri cenderung mengabaikan larangan, bahkan yang lebih parah lagi, umat Islâm sendiri menjadi "mustahzi'ûn" (orang yang mengolok-olok) ajaran agamanya sendiri. Ironis sekali mereka tidak memberikan kontribusi dengan ijtihâd baru terhadap agamanya, justru menjadi pelaku ribâ. Lihat saja sampai saat ini masih banyak kaum Muslim awam yang menganggap sistem bunga perbankan dan keuangan dapat menumbuhkan ekonomi masyarakat, padahal menurut Islâm, itu justru merusak perekonomian.13 Mereka berpandangan seperti itu karena banyak faktor: Pertama, pengaruh pendidikan Barat, yang mengajarkan sistem kapitalisme; kedua pengaruh lingkungan dimana masyrakatnya sudah terbiasa hidup dengan sistem bunga sehingga masyarakat beranggapan tidak ada masalah dengan perilaku ribâ; ketiga pengaruh minimnya informasi, keilmuan tentang ekonomi Islâm; dan keempat pengaruh perut, karena orang yang mencari penghidupan di lembaga ribâ terancam kehidupannya tanpa pekerjaan itu.

Dari berbagai reformasi yang dilakukan Nabî Muhammad saw, praktek ribâ mendapat sorotan yang sangat tajam. Ini terbukti dengan adanya beberapa ayat dan hadits yang juga mengecam ribâ dan menyebutnya sebagai perbuatan syetan, terkutuk dan dosa besar serta pelaku ribâ ini diancam masuk neraka.14 Dalam Kristen pun

11 Mervyn K. Lewis dan Latifa M. Algaod, Perbankan Syari'ah: Prinsip, Praktek dan Prospek, terj. Burhan ( Jakarta: PT. Serambi IImu Semesta, 2001), hlm. 240

12 lbid., hlm. 245

${ }^{13}$ Lihat al-Qur'ân surat al-Zumar (39): 39-41.

14 Pengharaman ribâ didahului oleh beberapa ayat yang menginformasikan tentang kekejian ribâ, ancaman dan akibat yang pernah menimpa kaum Yahudi karena 
pelarangan atau pembatasan yang sangat keras atas ribâ berlaku selama lebih dari 1.400 tahun, semua itu menunjukkan bahwa secara umum traksaksi berbasis bunga dilarang. Tetapi secara berangsurangsur kekuatan itu berubah sehingga ribâ hanya dimaknai dengan bunga yang terlalu tinggi, undang-undang ribâ yang melarang bunga yang berlebihan semacam itu masih berlaku hingga saat ini di banyak negara barat dan beberapa negara muslim. ${ }^{15}$ Dari sini jelas makna ribâ sudah mengalami reduksi dan mulai dikaburkan dan hanya diberlakukan pada ribâ yang berlipat ganda saja, padahal Islâm jelasjelas mengharamkan semua jenis/ bentuk ribâ dengan diturunkannya ayat yang terakhir yang memerintahkan "meninggalkan sisa-sisa perbuatan ribâ". 16

\section{Ribâ sebagai Puncak Krisis dan Akar Masalah Krisis}

Allâh sudah memberikan jawaban dalam al-Qur'ân bahwa akar masalah ke rusakan ekonomi adalah ribâ. ${ }^{17}$ Bahkan dalam semua kitab Samawi (Taurat, Injil dan al-Qur'ân), akar masalah yang paling utama adalah sistem ribâ yang menjadi instrumen dan jantung kapitalisme dalam seluruh transaksi keuangan, meskipun harus diakui ribâ bukan satu-satunya faktor akar terjadinya krisis finansial

mereka sering melakukan aktifitas ribâ baik dalam transaksi bisnis dan hutang piutang. Oleh karena itu diturunkan satu ayat yang mengharamkan ribâ yang berlipat ganda saja sampai kemudian turun ayat yang terakhir yang mengharamkan segala jenis dan bentuk ribâ, besar, kecil, berlipat ganda atau tidak. Ayat-ayat tersebut bisa dilihat dal am al-Qur'ân surat al-Rûm (30): 39; al-Nisâ' (4): 160-161; Ali I mrân (3): 130 dan al-Baqarah (2): 278 dan tidak kurang dari 12 hadits yang berbicara tentang ribâ dan keburukan-keburunannya.

${ }^{15}$ Sementara perjanjian baru memiliki 3 rujukan mengenai ribâ, perjanjian lama 4 rujukan. Tiga pasal tentang ribâ dalam perjanjian baru, dua diantaranya identik dan berhubungan dengan amsal uang (parable of the tal ent) (Matius 25: 14-30 dan Lukman 19:12-27). Keduanya bersikap ambigu mengenai ribâ, dalam Matius 25:27 disebutkan bahwa pelayan yang menegmbalikan uang sejumlah yang diterimanya, dulu, akan dihukum oleh tuan karena ia tidak "mengganti uangku, dan nanti ketika aku datang, aku harus menerima uangku. Ditambah bunganya". Jika diterjemahkan secara harfiyah, ayat ini kelihatannya memaafkan penarikan ribâ, namun pada saat yang sama si penerima dikecam karena "memungut (memanen) yang tidak kamu kabar (tanam) (Lukman, 19:21). Rujukan yang cukup jelas bisa dilihat dalam perjanjian baru; Lukman 6:35, Eksodus 22:25; Levatikus 25:35-37; Ulangan 23:19-20 dan Mazmur, 15:1-5.

16 Lihat al-Qur'ân surat al-Baqarah (2): 278

17 Al-Qur'ân surat al-Rûm (30): 39-41. 
tersebut, karena ada banyak analisis terkait dengan kehancuran pasar finansial, mulai dari kebijakan defisit AS, kebijakan suku bunga rendah di era greenspan, keserakahan elit politik, kegiatan spekulatif yang dilakukan oleh para petinggi perusahaan Dick Fuld-Ceo Lehman Brothers, tingginya biaya program politik luar negeri, manipulasi laporan keuangan dan masalah-masalah lain turut mengantarkan ke lembah krisis yang berkepanjangan, selalu terjadi dari satu periodeke periode berikutnya sampai saat ini terus berlangsung.

Semestinya para pakar itu sadar bahwa sistem ekonomi yang kita anut sekarang ini patut dipertanyakan kebenaran, kehebatan dan keampuhannya. Secara kasat mata saja, di atas yang saya kutip di depan sudah jelas-jelas bahwa sistem yang dianut dan dibanggakan ini sudah tidak memberikan kebaikan-kebaikan bahkan membawa penderitaan sepanjang sejarah. Umat Islâm yang krisis harus bertanya "apakah akar persoalan krisis dan resesi yang menimpa berbagai belahan dunia ini?".

Dalam menjawab pertanyaan di atas, cukup banyak para pengamat dan ekonomi mengemukakan analisisnya dari berbagai sudut pandang, sebab-sebab krisis tersebut antara lain: Pertama, kerapuhan fundamental ekonomi (fundamental economic fragility) adalah penyebab utama munculnya krisis ekonomi. Ekonomi yang mengalami inflasi yang tidak terkawal, defisit neraca pembayaran yang besar, pembatasan perdagangan yang berkelanjutan, kadar pertukaran mata uang yang tidak seimbang, tingkat bunga yang tidak realistik, beban hutang luar negeri yang membengkak dan pengaliran modal yang berulangkali, telah menyebabkan kesulitan ekonomi, yang akhirnya memerangkapkan ekonomi negara ke dalam krisi ekonomi. $18 \mathrm{~K}$ edua, kepincangan sektor moneter (keuangan dan sektor riil dalam Islâm dikategorikan dengan ribâ, sektor keuangan berkembang cepat meninggalkan jauh sektor riil. Ketiga, adanya transaksi ribâ. Islâm sangat mencela transaksi dirivatif ribâwi dan menghalalkan transaksi riil. Hal ini dengan tegas dinyatakan dalam al-Qur'ân bahwa Allâh menghalalkan jual beli dan mengharamkan ribâ. 19

\footnotetext{
18 Michel Camdessus (1997), "Lessons from Southeast Asia", IM F News, (13 N ovember 2008): http:/ / www.IMF.com ( Diakses pada 13 Maret 2009)

19 Lihat al-Qur'ân surat al-Baqarah (2): 175.
} 
Sebagaimana disebut di atas, perkembangan dan pertumbuhan finansial di dunia saat ini, sangat tak seimbang dengan pertumbuhan sektor riil. Realitas ketidakseimbangan arus moneter dan arus barang/ jasa tersebut, mencemaskan dan mengancam ekonomi berbagai negara. Pakar manajamen tingkat dunia, Peter Drucker, menyebut gejala ketidakseimbangan antara arus moneter dan arus barang/jasa sebagai adanya decopling, yakni fenomena keterputusan antara maraknya arus uang (moneter) dengan arus barang dan jasa. Fenomena ketidakseimbangan itu dipicu oleh maraknya bisnis spekulasi (terutama di dunia pasar modal, pasar valas dan proverti), sehingga potret ekonomi dunia seperti balon saja (bubble economy).20

Dalam ekonomi Islâm, jumlah uang yang beredar bukanlah variabel yang dapat ditentukan begitu saja oleh pemerintah sebagai variabel eksogen. Dalam ekonomi Islâm, jumlah uang yang beredar ditentukan di dalam perekonomian sebagai variabel endogen, yaitu ditentukan oleh banyaknya permintaan uang di sektor riel atau dengan kata lain, jumlah uang yang beredar sama banyaknya dengan nilai barang dan jasa dalam perekonomian.

Dikatakan pula, sektor finansial mengikuti pertumbuhan sektor riil. Inilah perbedaan konsep ekonomi Islâm dengan ekonomi konvensional, yaitu ekonomi konvensional, jelas memisahkan antara sektor finansial dan sektor riil. A kibat pemisahan itu, ekonomi dunia rawan krisis, khususnya negara-negara berkembang (terparah Indonesia). Sebab, pelaku ekonomi tidak lagi menggunakan uang untuk kepentingan sektor riel, tetapi untuk kepentingan spekulasi mata uang. Spekulasi inilah yang dapat menggoncang ekonomi berbagai negara, khususnya negara yang kondisi politiknya tidak stabil. A kibat spekulasi itu, jumlah uang yang beredar sangat tidak seimbang dengan jumlah barang di sektor riel.

Spekulasi mata uang yang mengganggu ekonomi dunia, umumnya dilakukan di pasar-pasar uang. Pasar uang di dunia ini saat ini, dikuasai oleh enam pusat keuangan dunia (London, New

20 Disebut ekonomi balon, karena secara lahir tampak besar, tetapi ternyata tidak berisi apa-apa kecuali udara. Ketika ditusuk, ternyata ia kosong. Jadi, bublle economy adalah sebuah ekonomi yang besar dalam perhitungan kuantitas moneternya, namun tak diimbangi oleh sektor riil, bahkan sektor riil tersebut amat jauh ketinggalan perkembangannya. 
York, Chicago, Tokyo, Hongkong dan Singapura). Nilai mata uang negara lain, bisa saja tiba-tiba menguat atau sebaliknya. Lihat saja nasib rupiah semakin hari semakin merosot dan nilainya tidak menentu.Di pasar uang tersebut, peran spekulan cukup signifikan untuk menggoncang ekonomi suatu negara. Lihatlah Inggris, sebagai negara yang kuat ekonominya, ternyata pernah sempoyongan garagara ulah spekulan di pasar uang, apalagi kondisinya seperti Indonesia, jelas menjadi bulan-bulanan para spekulan. Demikian pula ulah George Soros di Asia Tenggara.

Bagi spekulan, tidak penting apakah nilai menguat atau melemah. Bagi mereka yang penting adalah mata uang selalu berfluktuasi. Tidak jarang mereka melakukan rekayasa untuk menciptakan fluktuasi bila ada momen yang tepat, biasanya satu peristiwa politik yang menimbulkan ketidakpastian. Menjelang momentum tersebut, secara perlahan-lahan mereka membeli rupiah, sehingga permintaan akan rupiah meningkat. Ini akan mendorong nilai rupiah secara semu ini, akan menjadi makanan empuk para spekulan. Bila momentumnya muncul dan ketidakpastian mulai merebak, mereka akan melepas secara sekaligus dalam jumlah besar. Pasar akan kebanjiran rupiah dan tentunya nilai rupiah akan anjlok.

Globalisasi, khususnya dalam financial market, hanya membuat pemegang asset semakin memperbesar jumlah kekayaannya tanpa melakukan apa-apa. Dalam kacamata ekonomi Islâm, mereka meraup keuntungan tanpa 'iwadh (aktivitas bisnis riil, seperti perdagangan barang dan jasa riil). Mereka hanya memanfaatkan fasilitas-fasilitas yang terdapat dalam pasar uang dengan kegiatan spekulasi untuk menumpuk kekayaan mereka tan pa kegiatan produksi yang riil. Dapat dikatakan uang tertarik pada segelintir pelaku ekonomi meninggalkan lubang yang menganga pada sebagian besar spot ekonomi.21

Hahnel juga menyoroti bagaimana sistem kredit atau sistem hutang sudah merangkap perekonomian dunia sedemikian dalam. A palagi mekanisme bunga (interest rate) juga menggurita bersama sistem hutang ini. Yang kemudian membuat sistem perekonomian harus menderita ketidakseimbangan kronis. Sistem hutang ini

${ }^{21}$ Robin Hahnel, Capitalist Gl obalism In Crisis: U nderstanding the G lobal Economic Crisis: http:/ / en.wikipedia.org/ wiki/ Robin_Hahnel ( Diakses pada 20 Mei 2009) 
menurut Hahnel hanya melayani kepentingan spekulator, kepentingan segelintir pelaku ekonomi. Namun segelintir pelaku ekonomi tersebut menguasai sebagian besar asset yang ada di dunia. Jika kita kaji pemikiran Hahnel ini lebih mendalam akan kita lihat dengan sangat jelas bahwa perekonomian akan berakhir dengan kehancuran akibat sistem yang dianutnya, yakni kapitalisme ribâ.

Penasihat keuangan Barat, bernama Dan Taylor, mempunyai keyakinan bahawa sistem keuangan dan perbankan Islâm mempunyai keunggulan sistem yang lebih baik berbanding dengan sistem keuangan Barat yang berasaskan ribâ22. Krisis keuangan yang sedang dihadapi oleh negara-negara Barat seperti USA dan UK memberikan kekuatan secara langsung dan tidak langsung kepada sistem finansial Islâm yang berdasarkan syarî'ah.

Kembali kepada aktivitas ribâ para spekulan, bahwa mereka meraup keuntungan dari selisih harga beli dan harga jual. Makin besar selisihnya, makin menarik bagi para spekulan untuk bermain. Berdasarkan realitas itulah, maka Konferensi Tahunan Association of M uslim Scientist di Chicago, Oktober 1998 yang membahas masalah krisis ekonomi Asia dalam perspektif ekonomi Islâm, menyepakati bahwa akar persoalan krisis adalah perkembangan sektor finansial yang berjalan sendiri, tanpa terkait dengan sektor riil.

Dengan demikian, nilai suatu mata uang dapat berfluktuasi secara liar. Solusinya adalah mengatur sektor finansial agar menjauhi dari segala transaksi yang mengandung ribâ, termasuk transaksitransaksi maya di pasar uang. Gejala decoupling, sebagaimana digambarkan di atas, disebabkan, karena fungsi uang bukan lagi sekedar menjadi alat tukar dan penyimpanan kekayaan, tetapi telah menjadi komoditas yang diperjualbelikan dan sangat menguntungkan bagi mereka yang memperoleh gain. Meskipun bisa berlaku mengalami kerugian milyaran dollar AS.

Dapat dikatakan, perekonomian saat ini digelembungkan oleh transaksi maya yang dilakukan oleh segelintir orang di beberapa kota dunia, seperti London (27 persen), Tokyo-Hong Kong-Singapura (25 persen), dan Chicago-N ew York (17 persen). Kekuatan pasar uang ini sangat besar dibandingkan kekuatan perekonomian dunia secara

22 Achmad Kholiq, "Etika Bisnis dalam Perpektif Islam", pesantren news, (6 Januari 2009): http :/ / www.pesantrenvirtual.com. (Diakses pada 27 Februari 2009) 
keseluruhan. Perekonomian global praktis ditentukan oleh perilaku lima negara tersebut.

Islâm menolak keras segala jenis transaksi maya seperti yang terjadi di pasar uang saat ini. Sekali lagi ditegaskan, "Uang bukan komoditas". Praktek penggandaan uang dan spekulasi dilarang. Sebaliknya, Islâm mendorong globalisasi dalam arti mengembangkan perdagangan internasional. Globalisasi merupakan bagian integral dari konsep universal Islâm. Rasûlullâh telah menjadi pedagang internasional sejak usia remaja. Ketika berusia belasan tahun, dia telah berdagang ke Syam (Suriah), Yaman, dan beberapa negara di kawasan Teluk sekarang. Sejak awal kekuasaannya, umat Islâm menjalin kontak bisnis dengan Cina, India, Persia, dan Romawi. Bahkan hanya dua abad kemudian (abad kedelapan), para pedagang Islâm telah mencapai Eropa Utara. Ternyata nilai-nilai ekonomi syariah selalu aktual, dan terbukti dapat menjadi solusi terhadap resesi perekonomian.

Di zaman Nabî Muhammad jarang sekali terjadi resesi. Zaman khalîfah yang empat juga begitu. Pernah sekali Nabi mengalami defisit, yaitu sebelum Perang Hunayn, namun segera dilunasi setelah perang. Di zaman Umar bin Khaththâb (khalîfah kedua) dan Utsman (khalîfah ketiga), malah "APBN" mengalami surplus. Pernah dalam zaman pemerintahan Khalîfah Umar bin Abd al-'Azîz, tak dijumpai lagi satu orang miskin pun. Apa rahasianya? Kebijakan moneter Rasûlullâh saw -yang kemudian diikuti oleh para khalîfah- selalu terkait dengan sektor riil perekonomian berupa perdagangan. Hasilnya adalah pertumbuhan sekaligus stabilitas.

\section{Penutup}

Dari uraian-uraian di atas, dapat ditarik kesimpulan bahwa di era globalisasi dan gencarnya arus informasi, ekonomi syarî'ah mempunyai peranan yang signifikan sekali untuk dapat segera keluar dari krisis dunia yang selalu terjadi dari masa ke masa, karena selama kita melihat kinerja sektor keuangan yang berbasis syarî'ah, semakin hari kian diminati dan selalu menunjukkan peningkatan-peningkatan terutama di dunia perbankan.

Sedangkan ekonomi yang berbasis non syarî'ah, hingga saat ini sudah melalui beberapa kali krisis, dari sini nampak jelas bahwa paham ekonomi yang banyak dianut dunia (kapitalisme) ternyata 
tidak dapat memberikan kebehagiaan yang sejati kepada manusia, malah membawa, menggiring manusia kepada kesengsaraan yang hanya kaya yang kaya dan semakin miskin yang miskin, karena menganut falsafah individualisme mengenai ekonomi hak milik. Runtuhnya sistem ekonomi non syarî'ah ini, ditengarai karena, salah satunya, ia berbasis ribâ dalam bertransaksi. Hal ini sangat ditentang oleh ekonomi syarî́ah karena didalamnya terkandung banyak transaksi yang spekulatif seperti transaksi-transaksi diperbankan dan pasar modal (meskipun tidak semuanya) serta mengandung maysir (perjudian).

Oleh karena itu, momen beralih ke ekonomi syarî'ah menjadi keniscayaan bagi umat Islâm. Ini terbukti sistem kapitalisme barat dan ekonomi liberal yang dipaksakan tak mampu bertahan. Buktinya lagi hingga kini ekonomi Timur Tengah tak tersentuh krisis. Sehebat apapun krisis melanda dunia, Timur Tengah yang kerap mengedepankan syarî'ah tak tersentuh.

\section{D aftar Pustaka:}

Agustianto, Telaah Terhadap A kar Krisis Keuangan Global - M omentum Ekonomi Syariah Sebagai Solusi: Percikan Ekonomi Islam, http:/ / A gustianto.niriah.com. (Diakses pada 13 oktober 2008)

Camdessus, Michel "Lessons from Southeast Asia", IM F N ews, (13 N ovember 2008): http:/ / www.IMF.com (Diakses pada 13 Maret 2009)

Hahnel, Robin. Capitalist Globalism In Crisis: U nderstanding the Global Economic Crisis: http:/ / en.wikipedia.org/ wiki/ Robin Hahnel (Diakses pada 20 M ei 2009 )

IMF, "What the World Bank Is Doing",The Economic Crisis, (29 November 2008): http:/ / www.IMF.org./ External/ pubind , (Diakses pada 4 Januari 2009)

Jawa Pos, M adoff D ijebloskan ke Sel W C, 9 Maret 2009.

Jones, Down. “Dow Jones Is A Leading Provider Of Global Business News And Information Services", V ibiz news: http:/ / www.dow Jones. Com. (Diakses pada 29 Desember 2008)

Kholiq, Achmad “Etika Bisnis dalam Perpektif Islam”, Pesantren N ews, 
(6 Januari 2009): http :/ / www.pesantrenvirtual.com. (Diakses pada 27 Februari 2009)

Lewis, Mervyn K. dan Algaod, Latifa M. Perbankan Syari'ah: Prinsip, Praktek dan Prospek, terj. Burhan. Jakarta: PT. Serambi IImu Semesta, 2001.

Lubis, Suharwadi K. Hukum Ekonomi Islam. Jakarta: Sinar Grafika, 2004.

Manullag, Pengantar Bisnis. Yogyakarta: Gajah Mada University Press, 2002.

Sâyis, Muhammad 'Alî al-. Tafsîr Âyât al-A hִkâm. Beirut: Dâr al-Fikr, 1983.

Shabûnî, Muhammad 'Alî al-. Tafsir A yat al-A hkâm jilid I. Lebanon: al'Alamî, t.th.

STAN, Global Stock Market Ambruk: http:/ / www.exalumni.com/ exalumni// news.php? item.16. (Diakses pada 28 Desember 2008)

Swastha, Basu dan Sukotjo, Ibnu. Pengantar Bisnis M odern: Pengantar Perusahaan M odern. Yogyakarta: BPFE, 2001.

Syawkanî, Imam al-. Fath al-Q âdir jilid I. Beirut: Dâr al-Fikr, 1971.

Thabarî, al-. Tafsir al-Thabari, jilid I. Kairo: Dâr al-Kitab al-'A rabiy, 1951.

Tim Penulis MSI UII, M enjawab Keraguan Berekonomi Syariah. Yogyakarta: MSI UII dan Safiria Insania Press, 2008. 